\title{
New instruments for water management in Brazil
}

\author{
Gustavo Velloso Breviglieri, Guarany Ipê do Sol Osório and \\ Guilherme Borba Lefèvre \\ Centro de Estudos em Sustentabilidade (FGVces), Fundacao Getulio Vargas, \\ Sao Paulo, SP, Brazil
}

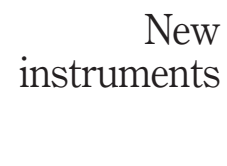

\begin{abstract}
Purpose - This paper aims to explore the possible uses of economic instruments, other than water tariffs, to assist water management policy in Brazil. In particular, the paper focuses attention toward markets for use rights.

Design/methodology/approach - The research is based on water resources specialists' opinions and perceptions, collected through surveys (Delphi method) and a focus group, to understand if such an instrument is desirable and which roles could it play within Brazilian water basins.

Findings - Results suggest there is room and utility for markets for water use rights, although mostly on a temporary basis, localized, predominantly dealing with scarcity events and in conjunction with the other instruments under Brazil's National Water Policy.

Originality/value - Given the persistence of scarcity events in the country, the research represents a first step to understand if new instruments for water management are politically feasible and contribute to better delineate future investigations applied to specific water basins and their local conditions.
\end{abstract}

Keywords Scarcity, Economic instruments, Markets for use rights, Water resources policy

Paper type Research paper

\section{Introduction}

Water is a scarce resource, and scarcity events have become increasingly more frequent in Brazil (ANA, 2017). Recent extreme weather events that affected Brazil's water resources sector[1] signal how important it is to promote tools and conduct deeper analyses that aim to bring greater resilience and responsiveness to this sector.

Historically, availability issues have been resolved by expanding the water supply through an engineering approach (Zetland, 2014). More recently, greater attention has been devoted to demand management as a way of avoiding scarcity events and, consequently, to the various economic instruments that can be deployed to increase water use efficiency and sustainability (Grimble, 1999; Filho \& Bondarovsky, 2000).

Brazil's National Water Resources Policy (Law No 9,433 from 1997) already recognizes water as a "limited natural [resource], endowed with economic value" and lists water use charges among its instruments (Brazil, 1997). However, such an instrument is still rarely

(C) Gustavo Velloso Breviglieri, Guarany Ipê do Sol Osorio and Guilherme Borba Lefèvre. Published in RAUSP Management Journal. Published by Emerald Publishing Limited. This article is published under the Creative Commons Attribution (CC BY 4.0) licence. Anyone may reproduce, distribute, translate and create derivative works of this article (for both commercial and non-commercial purposes), subject to full attribution to the original publication and authors. The full terms of this licence may be seen at http://creativecommons.org/licences/by/4.0/legalcode

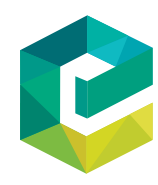

RAUSP Management Journal Vol. 55 No. 1, 2020 pp. $55-69$ 
RAUSP

55,1

applied, only in a small number of basins, and usually with values insufficient to substantially alter users' consumption patterns (OCDE, 2017).

It is then relevant to study whether other economic instruments can play a role within water management policies in the country, especially to minimize the negative impacts of scarcity events. Herein, we focus on markets for water use rights[2], which are soundly grounded in economic theory (Horbulyk \& Adamowicz, 1997; Landry \& Anderson, 2000; Griffin, 2016) and have already been adopted in some international jurisdictions (Johansson et al., 2002; Saleth et al., 2016).

This paper, thus, represents an exploratory and qualitative investigation, starting from a brief literature review and then surveying experts' opinions through questionnaires (Delphi method and focus group). We hope that our results will contribute to deepening the knowledge about possible pathways and strategies that can make water resources management in Brazil less vulnerable to scarcity events, particularly considering the most stressed water basins.

\section{Literature review}

\section{Economic instruments and water resources}

Water is an economic good prone to the situation known as "tragedy of the commons" and negative externalities (Hanley et al., 2007); water management tends to suffer from information asymmetries between users and planners and, consequently, requires flexibility. Even in the presence of these market failures[3], economic theory recognizes that clear property (or use) rights and the price system are the best way to govern the use of a given good or resource toward its best and most valuable uses (Fullerton \& Stavins, 1998; Cantin et al., 2005).

In the absence of prices that signal how scarce water really is, extraction and consumption patterns tend to occur at superior rates than the socially optimal (Johansson et al., 2002; Olmstead \& Stavins, 2007). Changes in the incentives faced by users, indicated by the price system, can also lead to faster responses to deal with scarcity events (Zetland, 2011).

When jurisdictions move from a centralized water allocation system (command and control regulations) to the use of market instruments, they transfer power from regulatory bodies to users. In this course, they usually relieve themselves from the responsibility of investing large sums of money to increase water supply through infrastructure projects (Rosegrant \& Gazmuri, 1994).

However, the transition from theory to practice needs to be accompanied by a first caveat: markets for water use rights, or simply water markets, are an instrument to reallocate use or access rights, usually by specifying a given quantity (volume) to be extracted or consumed at a certain time, place and conditions, as granted by the appropriate public authority. Therefore, they do not involve transferring water per se (Campos \& Studart, 2002). Generally, water markets mirror water use charges: from an initial cap on the amount of water to be used, the price associated with the use of the resource is discovered through voluntary transactions.

In addition, these markets are embedded within social and political contexts and interact with other institutions, not necessarily leading to efficient nor effective solutions to water management (Breviglieri et al., 2018). For instance, changing use patterns due to transactions of water rights can negatively affect return flows and aggravate scarcity events (Loch \& Adamson, 2015). 

transferred between users, users' associations, water districts[4] or public authorities (such as water banks).

Despite the theoretical relevance of this instrument, practical applications remain rare (Griffin, 2016). Some exceptions can be found in jurisdictions frequently exposed to scarcity events. For example, Breviglieri et al. (2018) analyze the initiatives from the Murray-Darling Basin (MDB) in Australia; the Colorado Big-Thompson (CB-T) Project and the Program between Palo Verde Irrigation District (PVID) and Metropolitan Water District (MWD) in the USA; and Spain, at a national level.

The MDB case is worthy of attention given how water use rights were redesigned following a series of policy reforms beginning in the 1990s. These rights were:

- unbundled from land titles; and

- split into-long term access rights to a nominal volume of water (entitlements) and annual allocations, stipulated as percentages of the entitlements and adjusted according to water levels in MDB's reservoirs (NWC, 2013).

Both the long-term and annual titles can be traded. This feature confers great flexibility to water users in the basin and leads to a highly active water market; more than 60 per cent of the farmers in the region engage in at least one transaction annually (Wheeler, 2014).

Although water rights are theoretically tradable in the American West, some regulatory doctrines restrict negotiations to those situations in which return flows and downstream users are not negatively affected (Squillace \& McLeod, 2016). In this sense, occurrences of water markets are mostly attached to infrastructure projects such as the CB-T, which transports water from one side to the other of the Rocky Mountains in Colorado, and the Colorado River Aqueduct, which delivers the waters of Colorado River for various districts in California.

In the first case, in 1957, the newly transposed water was allocated through the sale of homogeneous and, consequently, transferable quotas between the users served by CB-T. These quotas are also adjusted annually according to the water conditions of the region. Since then, water use became more urban but obeys the maximum volume to be delivered each year by the Project[5] (Howe, 2011). In the second case, an umbrella contract enacted in 2005 between two water districts established the conditions for farmers within PVID to rest part of their lands, renouncing some water use and releasing this volume for extraction by MWD; payments to each farmer are determined by the number of hectares not used for agricultural production each year (MWD, 2013).

Last, since its Water Law of 1999, Spain has attempted to foster water markets through:

- temporary transfers of water use rights between users; and

- water banks, in which public authorities manage short and long term transfers (Gómez \& Solanes, 2011).

Albeit water rights in the country are perceived as fragile, attached to land and subject to discretionary modifications by the government (Berbel \& Martin-Ortega, 2012), transactions remain rare and tend to occur only during extreme scarcity events, when the gains from trading more than compensate the risks and bureaucratic processes associated with each negotiation (Gómez \& Solanes, 2011). 
RAUSP

55,1

Even though the examples above are somewhat context-specific, they can still inspire water planners and managers in other jurisdictions. As scarcity events become more frequent in some Brazilian basins, water markets may represent an attractive alternative to allocate the available supply of water between different and competing uses.

\section{Markets for water use rights within Brazil's legal framework}

In Brazil, water resources are public domain (Brazil, 1997), of common use, and therefore inalienable (Brazil, 1988, Art. 225; 2002, Art. 100). The main legal foundation for water management in the country is Law No. 9,433/1997, which establishes the National Water Resources Policy (PNRH, acronym in Portuguese) and aims to contribute to the rational and adequate use of water resources, ensuring their availability to present and future generations (Brazil, 1997).

This Law also characterizes water basins as the territorial unit for the implementation of the PNRH and lists as its instruments the water permits (use rights, known as outorgas) and water use charges, among others. Use charges seek to reinforce the idea that water is an economic good by offering an indication of water's real value to users. Consequently, they incentivize the rational consumption of a scarce resource and provide funds to enact the programs and projects listed in water management plans (Brazil, 1997; OCDE, 2017).

Some authors (Porto \& Porto, 2008) interpret Law No 9,433/1997 as being considerably flexible, thus allowing the adaptation of its instruments to each basin's context without explicitly requiring the adoption of all these instruments in a single basin or limiting local water management exclusively to them.

The granting of a water permit does not imply the (partial) alienation of water; it simply gives the user the right to extract and consume a given volume of water under certain circumstances (Brazil, 1997, Art. 18). Hence, it is possible to say that water use rights' transactions do not lead to the alienation of water and, for that reason, would not be necessarily deemed unconstitutional[6]. Therefore, it is relevant to study and explore the potential of other economic instruments, beyond water use charges.

\section{Methods}

Public policies, uncertainties and the Delphi method

Public policy analysis is often made more difficult due to incomplete or insufficient information (Dalkey, 1969). However, an exploratory and prospective study concerning instruments about which there are, naturally, no data available can still gather experts' opinions to build the best possible picture about the problem at hand.

In this sense, this paper relies primarily on the use of questionnaires, inspired by the Delphi method, and a focus group. Such a combination of strategies aims to:

- ensure that all possible options have been taken into consideration; and

- examine and investigate the level of public acceptancy; technical feasibility; and convenience of all proposed options (Turoff, 2002).

The Delphi method was conceived to be applied with experts, especially in those instances where various stakeholders have limited knowledge over the topic at hand, and all would benefit from the interaction with other individuals who possess different information and viewpoints (Rowe \& Wright, 1999).

This method, therefore, consists of multiple rounds of research in which the participants reveal their impressions and opinions anonymously. After each round, answers are summarized and reported back to the participants in a new round of 
questions (Graefe \& Armstrong, 2011). Such an approach is appropriate for policy discussions in contexts of considerable uncertainty (Loe, 1995).

The focus group, in turn, is a form of group interview suitable for qualitative researches, enabling the identification of those areas of agreement or disagreement among participants. Hence, it is particularly relevant for applying open-ended questions, testing new concepts and previously unexplored themes and complementing qualitative researches based on other methods (Kitzinger, 1995). When applied in conjunction with the Delphi method, a focus group tests the adequacy of earlier inquiries, contextualizes and offers explanations for the results retrieved from the various rounds of questionnaires (Kidd \& Parshall, 2000; Kind, 2004).

\section{Development and application of questionnaires}

Initially, experts were recommended by the technical staff of Brazil's National Water Agency (ANA, acronym in Portuguese) and included Agency members and prominent names in the literature on water governance and legislation in the country. Through a snowball process[7], participants suggested that other individuals they thought could also take part in the survey.

Invitations were sent electronically, and resent at least one time, to 69 experts. Response rates from the first and second round of questionnaires were 27.5 per cent (19 answers) and 24.6 per cent (17 answers), respectively. The group of respondents was composed of members from governmental bodies (37.5 per cent of the total); academia (12.5 per cent); water basin committees (12.5 per cent); civil society organizations (12.5 per cent); multilateral cooperation organizations (4.2 per cent); and others[8] (20.8 per cent)[9].

Questionnaires were based on the literature review and shared with staff members from the Superintendency of Water Resources Planning at ANA for suggestions and refinements before their application. The first round of questions was made available to participants between September 6 and October 3, 2016, via an online form.

Questions for the second round included additional information to contextualize the analysis or test arguments concerning certain options previously not explored by the participants; such practice is compatible with the Delphi method (Rowe \& Wright, 1999). In particular, the participants were confronted with examples from markets for water use rights in international jurisdictions and asked if any of those cases resembled some of their answers from the first round and could serve as inspiration for Brazil. This round was made available between October 17 and November 11, 2016, also via an online form.

Both rounds presented the following research question to the participants: "If desirable, how can water markets be adopted in Brazil to reduce water scarcity events and increase water use efficiency?". They also included a definition of the term "water markets" to guide the answers:

Mechanism through which water users voluntarily trade (reallocate) their rights to use (or extract) water, partially or fully, on a temporary or permanent base, according to their own needs and obeying whatever conditions imposed by a regulatory or governing body.

Questions were multiple-choice, with room for justifications and comments. Participants had to select at least one option, as suggested by Turoff (2002). Last, a focus group was held on December 8, 2016, at ANA's premises in Brasília with the participation of eight members from the Agency's technical body. 
RAUSP

55,1

60

\section{Results}

Rounds of questionnaires

Answers to multiple-choice questions are presented below according to the level of consensus (percentage of answers) over each option; comments and justifications are identified according to the respondents' segment of action (AC - Academia; BC - Water Basin Committee; CS - Civil Society; GB - Governmental Body; MC - Multilateral Cooperation; OT - Others), similarly to that adopted by Couto \& Ribeiro (2016). Comments were translated from Portuguese by the authors (Table I).

Most participants see increased efficiency as the only or at least one of the goals to be achieved with a water market. However, respondents do not believe such an instrument should be implemented in isolation. Some comments reinforce the idea that there is no "savior instrument" (CS2) or "silver bullet" (GB/OT) for water management and that the set of instruments adopted at a given location should "reflect its conditions and characteristics" (GB6, IC1) (Table II).

With regard to the obstacles preventing water markets from being implemented in the country, those who pointed toward political reasons highlighted the lack of understanding by the general public over the term "water market" and to the possible confusions with the idea of "privatizing a state-owned good" (GB1, 2 and 3, GB/OT). Even among experts, such confusion can emerge. For instance, some respondents who signaled the existence of legal barriers declared that "water is constitutionally a state-owned good, public and of the common use of the people" (OT1, CS1, AC2, GB/BC1) (Table III).

Despite the answers provided in Question 2, 74 per cent of participants deem it desirable that water management policies in the country include water markets. Therefore, it is relevant to study the best ways to insert this instrument within Brazil's regulatory framework. The remaining questions seek to detail the preferable characteristics for these markets according to the experts (Table IV).

Participants understand that water markets should, primarily, cover the entirety of a water basin, which is "the legal management unity for water resources" (AC2). Nevertheless, an application at a smaller scale seems more feasible to them, given the higher levels of "control and knowledge about water stocks and their users" (GB1) (Table V).

All respondents agree that consumptive uses should be covered by a market; some indicate that non-consumptive uses should also be part of the instrument, as "both uses depend on the availability of water" (OT1) and, for instance, non-consumptive uses could "buy water use rights from upstream users" (GB1) (Table VI).

Finally, the majority of the participants agree with the use of water permits (outorgas) as the title to be transferred in a market, but some caveats are made: "water permits are still not legally safe and well defined in Brazil" (IC1); it is necessary to clarify to users the difference between "a use right", as represented by water permits, and "water ownership" (GB/OT); and "adjustments to the law would be necessary" (GB2).

The relationship between markets for use rights and the instruments listed in the PNRH was also explored in the second round of questionnaires. Its questions, answers and comments are presented below (Table VII).

With regard to the relationship between a possible water market and water use charges, the answers suggest a slight preference for transfers within a market to take place only temporarily and during specific moments, such as extreme scarcity events, given that "under normal circumstances, the signal provided by use charges should already incentivize the most efficient uses of water" (GB3) (Table VIII).

The majority of the participants agree with the use of monetary transactions between users within negotiation processes to ration water during crises. Among those that disagree 
with this proposal, objections relate to the belief that water rationing should be "based on technical criteria, obeying water use priorities" (GB6) (Table IX).

With regard to the role to be performed by water basin committees, these bodies' current and probable "technical limitations" (GB5) represent a risk that most respondents would prefer not to attach to the design of water markets. On the other hand, these committees

\section{New instruments}

\begin{tabular}{lll}
\hline Question 1 & Answers & $\%$ of answers \\
\hline
\end{tabular}

What is the major goal to be achieved with a water market?

$\begin{array}{ll}\text { Increase water use efficiency } & 88 \\ \text { To deal with emergency situations } & 56 \\ \text { Promote water conservation } & 31\end{array}$

Source: Research data. Obs.: Participants were allowed to select more than one alternative

Table I.

\begin{tabular}{llc}
\hline Question 2 & Answers & $\%$ of answers \\
\hline What is the nature of the reasons that can hinder the adoption of & Political & 50 \\
water markets in Brazil? & Legal & 44 \\
& Administrative & 6
\end{tabular}

Source: Research data

Table II.

\begin{tabular}{llc}
\hline Question 3 & Answers & \% of answers \\
\hline $\begin{array}{lll}\text { Is it desirable that water resources management in Brazil could rely on water } \\
\text { markets as an allocation mechanism? }\end{array}$ & Agree & 74 \\
Disagree & 26
\end{tabular}

Source: Research data

Table III.

\begin{tabular}{|c|c|c|}
\hline Questions 4 and 5 & Answers & $\begin{array}{c}\% \text { of } \\
\text { answers }\end{array}$ \\
\hline $\begin{array}{l}\text { Which geographical scale would be (most) desirable for the } \\
\text { adoption of water markets? }\end{array}$ & $\begin{array}{l}\text { Water basin } \\
\text { Water sub-basin } \\
\text { Reservoir } \\
\text { Areas integrated by } \\
\text { infrastructure projects }\end{array}$ & $\begin{array}{l}79 \\
21 \\
16 \\
47\end{array}$ \\
\hline $\begin{array}{l}\text { Which geographical scale would be (most) feasible for the } \\
\text { adoption of water markets? }\end{array}$ & $\begin{array}{l}\text { State } \\
\text { Water basin } \\
\text { Water sub-basin } \\
\text { Reservoir } \\
\text { Areas integrated by } \\
\text { infrastructure projects }\end{array}$ & $\begin{array}{l}10 \\
53 \\
21 \\
32 \\
37\end{array}$ \\
\hline
\end{tabular}

Source: Research data. Obs.: Participants were allowed to select more than one alternative. No participant chose the options "national", "state" or "city" on Question 4 or "national" or "city" on Question 5 (alternatives also offered in the questionnaire)

Table IV. 


\section{RAUSP}

55,1

\begin{tabular}{lllr}
\cline { 2 - 3 } Question 6 & Answers & \% of answers \\
\cline { 2 - 4 } & In a market, water use rights transfers should involve: & Consumptive uses & 16 \\
& & Non-consumptive uses & 0 \\
& Both, but separately & 26 \\
& Both, simultaneously & 58
\end{tabular}

Table V.

Source: Research data

\begin{tabular}{lll}
\hline Question 7 & Answers & $\%$ of answer \\
\hline Water permits (outorgas), as defined in the PNRH, can be used as the title to be & Agree & 63 \\
traded in a market? & Disagree & 37
\end{tabular}

Table VI.

Source: Research data

\begin{tabular}{llc}
\hline Question 8 & Answers & \% of answers \\
\hline How do you think water tariffs (according to & Simultaneously. At all times & 23 \\
water use) and water markets should be adopted? & $\begin{array}{l}\text { Simultaneously. With water markets } \\
\text { used only during (extreme) droughts }\end{array}$ & 54 \\
& Alternatively & 23
\end{tabular}

Table VII.

Source: Research data

\begin{tabular}{llc}
\hline Question 9 & Answers & $\%$ of answers \\
\hline Water rationing during scarcity events could rely on financial compensations & Agree & 76 \\
between users? & Disagree & 24
\end{tabular}

Table VIII. Source: Research data

\begin{tabular}{llc}
\hline Question 10 & Answers & \% of answers \\
\hline What is the most adequate role for Water Basin & $\begin{array}{l}\text { Necessary, responsible for the } \\
\text { design }\end{array}$ & 18 \\
$\begin{array}{l}\text { Committees } \\
\text { with regards to water markets in Brazil? }\end{array}$ & $\begin{array}{l}\text { Necessary, participating in the } \\
\text { design } \\
\text { Desirable, participating in the } \\
\text { design } \\
\text { Neither desirable nor necessary }\end{array}$ & 41 \\
& & 24
\end{tabular}

Table IX.

Source: Research data 
present opportunities "for discussions within technical chambers as well as financial resources" $(\mathrm{BC} 1)$ that could be useful at least during the conception stages of the instrument (Table X).

Here, the participants confirm the results obtained in Question 6: they agree that nonconsumptive users should also participate in the market, as any other user or possibly just acting as buyers (Table XI).

The consensus that appeared to be formed on Question 7 regarding the use of water permits as the only title to be transferred in a market is refined here: nearly half of the participants have reservations concerning the use of the instrument as it is currently conceived and inspected. Indeed, "the establishment of a water market could present an opportunity to review the hydrological parameters for granting permits" (GB6). Despite its unattractiveness to the respondents (only 24 per cent of agreement), the creation of a new title (annual allocations) is actually responsible for the intense activity seen in in the MDB water market (Table XII).

Last, even though the answers show the majority of participants agreeing that infrastructure projects offer a promising path for the establishment of water markets, it is not possible to derive which projects would be most suitable for that purpose. While one respondent suggests that projects that attend to "multiple uses" would be appropriate for

\begin{tabular}{llc}
\hline Question 11 & Answers & \% of answers \\
\hline How do you imagine non-consumptive users should & Buying and selling rights & 71 \\
participate in a market? & Exclusively buying rights & 11 \\
& They should not participate & 18
\end{tabular}

Source: Research data

Table X.

\begin{tabular}{llr}
\hline Question 12 & Answers & $\begin{array}{c}\% \text { of } \\
\text { answers }\end{array}$ \\
\hline $\begin{array}{l}\text { How should water permits (outorgas) be used } \\
\text { within a water market? }\end{array}$ & $\begin{array}{l}\text { As the only tradable title } \\
\text { As a basis for the creation of a new title }\end{array}$ & 30 \\
& $\begin{array}{l}\text { Both as the basis for the creation of a new title } \\
\text { and as a tradable title itself } \\
\text { It should not be used in its current form }\end{array}$ & 18 \\
&
\end{tabular}

Source: Research data

Table XI.

\begin{tabular}{llc}
\hline Question 13 & Answers & \% of answers \\
\hline Infrastructure projects that increase water supply could & Yes, for every project & 25 \\
rely on water markets (to allocate this supply)? & Yes, but only for new projects & 25 \\
& Yes, but only for some projects & 25 \\
& No & 25
\end{tabular}

Source: Research data

Table XII. 
RAUSP

55,1

such an instrument (OT1), another state that "water infrastructure dedicated to human supply could be excluded” from a potential market (GB1).

\section{Focus group}

The focus group sought to criticize, contextualize and refine the results found in the two rounds of questionnaires. Given the complementary character of this research stage, the main contributions are grouped and summarized below, according to specific subjects and reflecting participants' opinions. The ideas presented do not necessarily imply consensus between all respondents, but they ensure that all topics and opinions discussed throughout the meeting are offered. Our interpretation of all results is given in the following section.

Preconditions for the establishment of a market. Whatever the design imagined for a market for water use rights in Brazil, such an instrument can only be adopted in those instances where each user's consumption is measured and reported, for instance with meters. It is essential to know precisely how much water each user is collecting.

Geographic scale. There is no single market arrangement that can be equally and appropriately applied to all water basins in the country. Therefore, it is reasonable to assume that water markets should be indicated to sub-basins, river stretches, dams or other dimensions smaller than a water basin.

Time scale. In regularized basins, the managing body has the responsibility to control an increasing demand for water resources, either when issuing new water permits or when inspecting existing uses according to the conditions established in those permits. Thus, it seems consensus that the use rights should only be traded during scarcity periods, particularly due to variations in water supply.

In these instances, service for all users in the same water system is compromised, and the authorized flows for abstraction could be adjusted, in a coordinated way, by the managing body through clearly specified rules within a (socially) negotiated allocation term[10]. After the granting authority proposes an initial decrease in the volumes to be used, it is possible to imagine the opening of a negotiation and transactions window where users voluntarily exchange the volumes associated with these reduction commitments.

If any two users reach a financial agreement[11] (buyer agreeing to reduce less of her water consumption and seller performing deeper cuts in her uses), it would suffice to simply inform the managing body. This body would then formalize the agreement, adjust the negotiated allocation term and start to monitor the new agreed upon volumes for each user (for as long as the scarcity event lasts).

This kind of arrangement has the advantage of only entering into force with the consent of all users and assuring that the total amount of water to be extracted from a given water system is always respected. Likewise, it is clear that each individual user is also constrained to the (maximum) nominal volume established in her permit.

If, on the one hand, water markets are adopted according to the premises above, they would be short-lived instruments; on the other hand, a more temporary character is more amenable to making gradual adjustments and allowing users to learn as they transact or observe other users in their surroundings engaging in such negotiations.

Relationship with the existing framework and pathways for adopting water markets. Depending on the design of a water market, the processes for granting water use rights may be an obstacle for adopting such an instrument. Currently, these procedures are not flexible and would result in high transaction costs for any market that requires frequent trades between users.

Indeed, within the existing regulatory framework, it is possible to see water permits as being attached to the commercial venture until their expiration date. At least, users 
frequently appear to understand the rules this way; it is not uncommon for those productive units that already possess a granted water right to fetch higher market values in comparison to properties lacking such a right.

If water permits (outorgas) become the title to be traded within a market or serve as the basis for the creation of another title, some caveats will not be solved: current legislation clearly defines water permits as precarious and subject to review at any moment. There is room, however, to perfect this instrument, for instance: if a water basin decides to adopt a water market then, for that basin, water permits could be composed of both a fixed volume (to be supplied in any circumstances) and a tradable volume.

Even though markets for use rights can be legally inserted into water management at higher regulatory levels, for instance in the form of federal law, it is also important to recognize those proposals and ideas stemming from users themselves and, thus, fitting to their local conditions. Actually, water management tends to fare better when general laws create a given mechanism, but its regulation is delegated to inferior levels and done via infralegal rules. Moreover, the recognition of water markets in federal law does not appear to be indispensable, although it could enhance its (perceived) legal security.

Water resource plans[12], for example, offer a favorable environment to the proposal and discussion of new instruments. In this context, it is possible to take advantage of such a moment of intense mobilization between the main actors concerned with water management in a certain basin and consider a new experience.

Water basin committees should participate in a water market in a more consultative rather than deliberative or operational manner. For instance, a committee could suggest and highlight some general guidelines, including those contained in a water resources plan, to the managing body responsible for granting water rights and running the market and to users.

Taking into consideration the innovative character of a market instrument, it is reasonable to postulate that initial applications could take the form of pilot projects within the existing framework. This way all stakeholders could familiarize with the instrument, understand its risks and advantages and, consequently, gather the necessary support for proposing and approving more ambitious and lasting changes to the water management processes in Brazil.

\section{Discussion and final remarks}

This article investigated if other economic instruments, particularly markets for water use rights, could play a role within Brazil's water management policies. Such an exercise is more productive if we recognize two inherent limitations to any good research based on economic theory. First, economic propositions are essentially conditional (if A, then B) (Rodrik, 2013); thus, answers to a given problem depend, at least partially, on the context that surrounds it and are not necessarily applicable to other situations.

Second, it is vital to compare any existing or proposed policies and instruments against real institutions and their observed effects, rather than against idealized notions in scenarios of fictitious and perfect implementation (Demsetz, 1969). There is always noise in the transition from theory to practice.

Given the physical limitations for water extraction under sustainable levels in Brazilian water basins, markets for use rights could improve water use efficiency. The ensemble of answers obtained from our interviewees highlights the preference for a temporary, shortlived, localized application of a potential market. Administrative barriers, although present, appear to be small and inherent to water management and not to this new instrument. 
RAUSP

55,1

66

Thus, technically, water markets seem to be useful as indicated both by questionnaire respondents and the focus group. Legally, they do not explicitly hurt the existing framework and respect the inalienable character of the public water resources. These markets would only cover water use rights, as granted by a competent authority.

On the one hand, explicitly recognizing water markets at some level of the legal order governing water resources extraction and consumption would offer greater security for those managers and users interested in their adoption and implementation. On another, inserting these markets within the instruments listed in Law No 9,433, as suggested by Senate Bill 495/2017, could meet political opposition, with little technical foundation but sufficient to compromise any discussions over the best set of rules to meet societal needs.

Regardless, a water market would definitely interact with the current instruments in the PNRH, for instance, a market could:

- be based on the existing water permits (outorgas);

- be proposed, discussed, and recognized within water resources plans; and

- coexist, temporarily, with water use charges, especially during scarcity periods.

Indeed, scarcity events in the country already rely on moments (and rules) when rationing efforts can be socially negotiated among users. Hence, there is a promising entry point to experiment with market-based instruments: the possibility of bilateral negotiations between users could minimize the losses from these scarcity events with minimal impact to the existing regulatory framework.

In conclusion, in an exploratory fashion, the literature surveyed herein and the answers from the rounds of questionnaires and the focus group suggest that there is a role to be played by markets for water use rights in Brazil, even though solely under specific conditions such as during periods of considerable gap between the supply and demand of water. Although the Delphi method may (implicitly) direct participants toward a consensus (Hsu \& Sandford, 2007), at this initial stage, our general approach enabled us to delimit the frontiers for future studies. Further research can bring the discussions closer to the local realities of those water basins in which a water market could yield higher benefits.

\section{Notes}

1. Recent examples are the water crises in the Southeast region (2014-2016) and in the Federal District (2017-2018) as well as the intense scarcity period in the Northeast (2012-2017) (Sinimbú \& Matsuki, 2018).

2. Understood as the mechanism through which water users voluntarily trade (reallocate) their rights to use (or extract) water, partially or fully, on a temporary or permanent base, according to their own needs and obeying whatever conditions imposed by a regulatory or governing body (our definition).

3. The existence of market failures such as externalities may justify some governmental interventions. A possible way for governments to intervene is the creation of new markets.

4. In the United States of America, a water district is a "local, governmental entity that provides limited services to its customers and residents" (Texas Commission on Environmental Quality (TCEQ), 2015).

5. 313 thousand acre-feet per year. One acre-foot equals 1,233.48 cubic meters.

6. Our interpretation is similar to that of Senate Bill 495/2017 that seeks to list water markets as an additional instrument of the PNRH (Brazil, 2017). 
7. Sampling technique in which current participants suggest new ones in an iterative process until new interviewees no longer contribute with novel and relevant information (Seidman, 2006, p. 55).

8. Others: Consultancy firms, Water Basin Agencies and State Water Resources Councils.

9. Figures relating to the first round of questionnaires. Participants could self-identify as belonging to more than one organization, for instance, member of the academy and from a civil society organization.

10. According to Resolution No 129, July 2011, from Brazil's National Water Resources Council (CNRH, 2011).

11. Such an agreement could happen outside of the water resources (regulatory) system.

12. Another instrument listed in the PNRH.

\section{References}

ANA. (2017). Conjuntura dos recursos hídricos no Brasil 2017: Relatório pleno, Brasília: Agência Nacional de Águas.

Berbel, J.K., \& Martin-Ortega, J. (2012). Assessment of the draft hydrological basin plan of the guadalquivir river basin. International Journal of Water, 28, 43-55.

Brazil. (1988). Constituição da república federativa do Brasil, Brasília: DF Senado Federal.

Brazil. (1997). Lein ${ }^{\circ}$ 9.433, de 8 de janeiro de 1997, Brasília: DF Presidência da República.

Brazil. (2002). Código civil, lei 10.406, de 10 de janeiro de 2002, São Paulo, Brazil: Revista dos Tribunais.

Brazil. (2017). Projeto de lei do senado 495/2017, Brasília: DF Senado Federal.

Breviglieri, G.V., Osório, G.I., \& Oliveira, J.A. (2018). Understanding the emergence of water market institutions: learning from functioning water markets in three countries. Water Policy, 20, 1075-1091.

Campos, J.N., \& Studart, T.M. (2002). Alocação e realocação do direito de uso da água: Uma proposta de modelo de mercado limitado no espaço. Revista Brasileira de Recursos Hídricos, 7, 5-16.

Cantin, B., Shrubsole, D., \& Ait-Ouyahia, M. (2005). Using economic instruments for water demand management: Introduction. Canadian Water Resources Journal, 30, 1-10.

Chong, H., \& Sunding, D. (2006). Water markets and trading. Annual Review of Environment and Resources, 31, 239-264.

CNRH. (2011). Resolução n 129, de 29 de junho de 2011, Brasília: DF Conselho Nacional de Recursos Hídricos.

Couto, H.L., \& Ribeiro, F.L. (2016). Objetivos e desafios da política de compras públicas sustentáveis no Brasil: A opinião dos especialistas. Revista de Administração Pública, 50, 331-343.

Dalkey, N.C. (1969). The delphi method: an experimental study of group opinion, Santa Monica, CA: United States Air Force Project Rand.

Demsetz, H. (1969). Information and efficiency: Another viewpoint. The Journal of Law and Economics, 12, 1-22.

Filho, A.C., \& Bondarovsky, S.H. (2000). Água, bem econômico e de domínio público. R. Cej, 12, 13-16.

Fullerton, D., \& Stavins, R. (1998). How economists see the environment. Nature, 395, 433-434.

Gómez, C.M., \& Solanes, M. (2011). Water transfers in the tagus river Basin (Spain), Milan: EPI-Water (Fondazione Eni Enrico Mattei). 
RAUSP

55,1

Graefe, A., \& Armstrong, J.S. (2011). Comparing face-to-Face meetings, nominal groups, delphi and prediction markets on an estimation task. International Journal of Forecasting, 27, 183-195.

Griffin, R.C. (2016). Water marketing. In R.C. Griffin (Ed.), Water resource economics: The analysis of scarcity, policies, and projects (2nd ed., pp. 255-300) Cambridge, MA: MIT Press.

Grimble, R. (1999). Economic instruments for improving water use efficiency: Theory and practice. Agricultural Water Management, 40, 77-82.

Hanley, N., Shogren, J.F., \& White, B. (2007). Environmental economics in theory and practice, London, United Kingdom: Palgrave Macmillan.

Horbulyk, T.M., \& Adamowicz, W.L. (1997). The role of economic instruments to resolve water quantity problems. Rural Economy Project Report, Department of Rural Economy. Edmonton, Canada: University of Alberta.

Howe, C.W. (2011). The efficient water market of the Northern CO water conservancy District: CO. Milan: EPI-Water (Fondazione Eni Enrico Mattei).

Hsu, C.C., \& Sandford, B.A. (2007). The delphi technique: Making sense of consensus. Practical Assessment, Research and Evaluation, 12, 344-347.

Johansson, R.C., Tsur, Y., Roe, T.L., Doukkali, R., \& Dinar, A. (2002). Pricing irrigation water: A review of theory and practice. Water Policy, 4, 173-199.

Kidd, P.S., \& Parshall, M.B. (2000). Getting the focus and the group: Enhancing analytical rigor in focus group research. Qualitative Health Research, 10, 293-308.

Kind, L. (2004). Notas Para o trabalho com a técnica de grupos focais. Psicologia em Revista, 10, $124-136$.

Kitzinger, J. (1995). Qualitative research: Introducing focus groups. BMJ, 311, 299-302.

Landry, C., \& Anderson, T. (2000). The rising tide of water markets. ITT industries guidebook to global water issues.

Loch, A., \& Adamson, D. (2015). Drought and the rebound effect: A murray-darling basin example. Natural Hazards, 79, 1429-1449.

Loe, R.C. (1995). Exploring complex policy questions using the policy delphi: A multi-round, interactive survey method. Applied Geography, 15, 53-68.

Metropolitan Water District (MWD). (2013). Palo verde land management, crop rotation and water supply program: At a glance, Los Angeles, CA: MWD of Southern CA.

National Water Commission (NWC). (2013). Australian water markets: Trends and drivers $2007-08$ to 2011 - 12, Canberra, Australia: NWC.

OCDE. (2017). Cobranças pelo uso de recursos hídricos no Brasil: Caminhos a seguir, Paris: Éditions OCDE.

Olmstead, S.M., \& Stavins, R.N. (2007). Managing water demand: Price vs. Non-Price conservation programs, Boston, MA: Pioneer Institute.

Porto, M.F., \& Porto, R.L. (2008). Gestão de bacias hidrográficas. Estudos Avançados. advance online publication. http://dx.doi.org/10.1590/S0103-40142008000200004

Rodrik, D. (2013). What use are economists? Retrieved from www.project-syndicate.org/commentary/ the-provisional-nature-of-economic-research-by-dani-rodrik?barrier

Rosegrant, M., \& Gazmuri, R. (1994). Reforming water allocation policy through markets in tradable water rights: Lessons from Chile, Mexico, and CA, Washington, DC: Environment and Production Technology Division, International Food Policy Research Institute.

Rowe, G., \& Wright, G. (1999). The delphi technique as a forecasting tool: Issues and analysis. International Journal of Forecasting, 15, 353-375.

Saleth, R. M., Bassi, N., \& Kumar, M. D. (2016). Role of institutions, infrastructures, and technologies in meeting global agricultural water challenge. Choices, 31, 1-7. 
Sinimbú, F., \& Matsuki, E. (2018). Reviravolta no mapa da seca. Retrieved from www.ebc.com.br/ especiais-agua/reviravolta-no-mapa-da-seca/

Squillace, M., \& McLeod, A. (2016). Marketing conserved water. Environmental Law, 46, 1-47.

Texas Commission on Environmental Quality (TCEQ. (2015). Water districts. Retrieved from www. tceq.texas.gov/waterdistricts/

Turoff, M. (2002). The policy delphi. In M. Turoff \& H. Linstone (Eds.), The delphi method: Techniques and applications (pp. 80-96), Boston, MA: Addison-Wesley Educational Publishers.

Wheeler, S. A. (2014). Insights, lessons and benefits from improved regional water security and integration in Australia. Water Resources and Economics, 8, 57-78.

Zetland, D. (2011). The beginning of the end. In D. Zetland (Ed.), The end of abundance: Economic solutions to water scarcity (1.2 ed. pp. 2-23) Mission Viejo, CA: Aguanomics Press.

Zetland, D. (2014). Living with water scarcity. Mission Viejo, CA: Vancouver.

Corresponding author

Gustavo Velloso Breviglieri can be contacted at: gustavo.velloso@fgv.br

Associate editor: Matheus Albergaria

For instructions on how to order reprints of this article, please visit our website: 